\title{
Prevalence of Enterotoxigenic Staphylococcus aureus Isolated From Chicken Nugget in Iran
}

\author{
Hajar Madahi ${ }^{1}$; Fatemeh Rostami ${ }^{1}$; Ebrahim Rahimi ${ }^{2,} ;$ Farhad Safarpoor Dehkordi $^{3}$ \\ ${ }^{1}$ College of Agriculture, Shahrekord Branch, Islamic Azad University, Shahrekord, IR Iran \\ ${ }^{2}$ Department of Food Hygiene and Public Health, College of Veterinary Medicine, Shahrekord Branch, Islamic Azad University, Shahrekord, IR Iran \\ ${ }^{3}$ Young Researchers and Elites Club, Shahrekord Branch, Islamic Azad University, Shahrekord, IR Iran \\ ${ }^{*}$ Corresponding author: Ebrahim Rahimi, Department of Food Hygiene and Public Health, College of Veterinary Medicine, Shahrekord Branch, Islamic Azad University, Shahrekord, \\ IR Iran. Tel:+98-9133278377, Fax:+98-3813381892, E-mail: ebrahimrahimi55@yahoo.com
}

Received: January 12, 2013; Revised: July 27, 2013; Accepted: April 5, 2014

\begin{abstract}
Background: The enterotoxigenic Staphylococcus aureus is considered as one of the most important cause of food poisoning that manifests with gastroenteritis, diarrhea, and vomiting. Its complications usually occur when bacterial virulence genes are produced. The most important virulence factors are cell-associated components, exoenzymes, exotoxins, enterotoxins, and enterotoxin-like toxins.

Objectives: The present study aimed to study the presence of $S$. aureus and its virulence factors in chicken nuggets in Iran.

Materials and Methods: Totally, 420 chicken nuggets from five brands were collected from Isfahan and Chaharmahal-va-Bakhtiari provinces, Iran. Samples were cultured and the positive results were studied using ELISA and PCR for detection of classical staphylococcal enterotoxins and sea-sej virulence genes, respectively.

Results: Results showed that 27 (6.42\%) of 420 samples were contaminated with S. aureus with bacteria concentration between $6.1 \times 10^{3}$ to $8.4 \times 10^{1} / \mathrm{mL}$. Totally, $33.33 \%$ of isolates produced SEA, $4.16 \%$ SEB, $12.50 \%$ SEC, $8.33 \%$ SED, $12.50 \%$ SEA + SEC, and $12.50 \%$ SEA + SED. The most commonly detected genes were sea (25\%), sea $+\operatorname{seg}(8.33 \%)$, sec (12.50\%), sea $+\operatorname{sed}(12.50 \%)$, and sea $+\sec +\operatorname{sej}(12.50 \%)$.

Conclusions: S. aureus can easily contaminate the chicken nugget and this contamination is usually associated with significant presences of virulence genes. Consumption of these nuggets certainly is associated with gastrointestinal diseases. Therefore, some food safety and quality standards should be applied and performed in most of the Iranian food units to control growth of S. aureus and its virulence factors.
\end{abstract}

Keywords: Staphylococcus aureus; Chicken nugget; Virulence Factors; Iran

\section{Background}

Staphylococcus aureus is a Gram-positive facultative anaerobic coccal bacterium that cans easily contaminate meat, food, and environment $(1,2)$. In humans, S. aureus is a well-documented opportunistic pathogen. It may cause food poisoning, pneumonia, skin infections, enterotoxemia, and septicemic infections; furthermore, it is important as the cause of toxic shock syndrome (TSS) $(1,3)$. S. aureus causes severe animal diseases such as mastitis, suppurative disease, arthritis, and urinary tract infections $(4,5)$. Many studies have shown that $S$. aureus can cause spoilage in poultry and its products $(6,7)$; its presence is tested in these products to assess the microbiological safety, hygiene conditions during processing (8), and storage quality of products.

Several potential virulence factors are important in staphylococcal infections and poisonings (9). Most of these factors have been studied in S. aureus. Its virulence factors can be divided into cell-associated components, exoenzymes, and exotoxins. Thus far, nine enterotoxins (SEA-SEE and SEG-SEJ) and nine enterotoxin-like toxins (SELK-SELR and SELU) have been identified in S. aureus (9-11). When ingested, staphylococcal enterotoxins (SEs) cause diarrhea and vomiting and are responsible for staphylococcal food poisoning. It is important to study the presence of these SEs in chicken meat and their products. Chicken nugget is a member of breaded fried food family that contains valuable food materials such as fat, protein, vitamins, and mineral. It is one of the most popular foods worldwide. Unfortunately, the heat processing of chicken nugget is very short (about two minutes) (8) and the possibility of the presence and growth of some resistance bacteria like $S$. aureus is expected. Hence, it is necessary to know which endemic strains of $S$. aureus in chicken meat and its products are highly pathogenic in Iran; however, there is no available data concerning this issue. In Iran, Javadi and Safarmashaei, Nemati et al. and 
Feizi et al. have shown the presence of S. aureus in chicken (12-14).

\section{Objectives}

To our knowledge, there is no studyconcerning detection of S. aureus and its virulence factors in poultry and its products in Iran. Therefore, the present study aimed to assess the prevalence of $S$. aureus and its enterotoxigenic virulence factors in chicken nugget in Iran.

\section{Materials and Methods}

\subsection{Sample Collection}

A total of 420 chicken nugget samples from five brands were collected from supermarkets and retailers in various parts of Isfahan and Chaharmahal-va-Bakhtiari provinces, Iran, from September 2010 to July 2011. The samples were immediately transported to the laboratory in a cooler with ice packs and were evaluated within an hour of collection.

\subsection{Detection of Staphylococcus aureus}

The samples were evaluated immediately upon arrival using aseptic techniques. All samples were culture and their biochemical properties were evaluated using the methods described by Kiedrowski et al. (15). Ten grams portion of each sample was added to $90 \mathrm{~mL}$ of sterile phosphate buffered saline and homogenized. Then microbiological processing of the samples for the isolation of S. aureus was performed using Baird Parker agar (Difco Laboratories, Detroit, Michigan, USA) through the standard procedure. Suspected colonies were subcultured on blood agar plate (Difco Laboratories, Detroit, Michigan, USA) and incubated for 24 hours at $37^{\circ} \mathrm{C}$. To identify S. aureus, Gram stain, catalase, mannitol fermentation, coagulase, and Voges-Proskauer (VP) tests were performed on suspected colonies.

\subsection{Detection of Classical Staphylococcal Enterotoxins}

To detect SEs, the isolates were cultured overnight aerobically in10 mL nutrient broth (Merck, Darmstadt, Germany) at $37^{\circ} \mathrm{C}$. Bacterial culture supernatants were collected by centrifugation at $4000 \times \mathrm{g}$ for ten minutes and were used for detection of SEA, SEB, SEC, SED, and SEE using an enzyme linked immunosorbent assay (ELISA) detection kit (RIDASCREEN@Set A, B, C, D, E [Art No: R4101, R-Biopharm AG, Darmstadt, Germany]). The assay was performed according to the manufacturer's instruction and description in literature (16). The mean lower detection limit of the assay was $0.1 \mathrm{mg} / \mathrm{mL}$. All experiments were performed in duplicate.
3.4. Detection of sea, seb, sec, sed, see, seg, seh, sei, and sej Genes

Purification of DNA was achieved using a Genomic DNA purification kit (Fermentas, GmbH, St. Leon-Rot, Germany) according to the manufacturer's instruction. The total DNA was measured at $260 \mathrm{~nm}$ optical density according to the method described by Sambrook and Russell (17). After DNA isolation, amplification of selected SEs genes (sea, seb, sec, sed, see, seg, seh, sei, and sej) was achieved using nine primer sets in the one reaction mixture. The sequences of the primers used for gene amplification are presented in Table 1 . All oligonucleotide primers were obtained from a commercial source (CinnaGen, Iran). Polymerase chain reaction (PCR) for the detection of SEs genes was performed according to the methods described previously (18). Briefly, amplification reactions were performed in a $25 \mu \mathrm{L}$ mixture containing $1 \mathrm{U}$ of Taq polymerase (Fermentas, GmbH, St. Leon-Rot, Germany), $200 \mu \mathrm{mol}$ of each dNTP (Fermentas, GmbH, St. Leon-Rot, Germany), $2.5 \mu \mathrm{L}$ of $10 \times$ PCR buffer (Fermentas, $\mathrm{GmbH}$, St. Leon-Rot, Germany), $1.0 \mu \mathrm{mol}$ of $\mathrm{MgCl}_{2}$ (Fermentas, $\mathrm{GmbH}$, St. Leon-Rot, Germany), 10 pmol of each primers, and $3 \mu \mathrm{L}$ of DNA.

The final volume was adjusted to $25 \mu \mathrm{L}$ by adding sterile ultrapure water (19). Amplification reactions were performed using a DNA thermal cycler (Master Cycler Gradient, Eppendorf, Germany) with the following program: denaturation for two minutes at $94^{\circ} \mathrm{C}$, annealing of primers for two minutes at $55^{\circ} \mathrm{C}$, and primer extension for one minute at $72^{\circ} \mathrm{C}$ with autoextension (30 cycles) for the sea, $s e b, s e c$, and sed genes; denaturation for 120 seconds at $94^{\circ} \mathrm{C}$, annealing of primers for 120 seconds at $57^{\circ} \mathrm{C}$, and primer extension for 60 seconds at $72^{\circ} \mathrm{C}$ ( 35 cycles) for the see gene; denaturation for 30 seconds at $94^{\circ} \mathrm{C}$, annealing of primers for 30 seconds at $55^{\circ} \mathrm{C}$, and primer extension for 60 seconds at $72^{\circ} \mathrm{C}$ (30 cycles) for the seg, seh, and seigenes; denaturation for 60 seconds at $94^{\circ} \mathrm{C}$, annealing of primers for 60 seconds at $62^{\circ} \mathrm{C}$, and primer extension for 60 seconds at $72^{\circ} \mathrm{C}$ (30 cycles) for the sej gene. The PCR products were stained with $1 \%$ solution of ethidium bromide and visualized under UV light after gel electrophoresis on 1.5\% agarose. S. aureus ATCC 19095, ATCC 23235, and ATCC 700699 were used as the positive controls and DNase-free water was used as the negative control.

\subsection{Statistical Analysis}

Data were transferred to Microsoft Excel spreadsheet (Microsoft Corp., Redmond, WA, USA) for analysis. Using SPSS 16.0 (SPSS Inc., Chicago, IL, USA), two-tailed chisquare test and fisher's exact test were employed for analysis and differences were considered statistically significant at $\mathrm{P}$ values $<0.05$. 
Madahi Het al.

Table 1. Primers and Temperature Used for the Detection of S. aureus Exotoxins Genes

\begin{tabular}{|c|c|c|c|c|c|}
\hline \multirow{4}{*}{ sea } & & Sequence & Base Pairs & Annealing Temperature, ${ }^{\circ} \mathrm{C}$ & Reference \\
\hline & & & 120 & 50 & $(20)$ \\
\hline & sea-1 & TTGGAAACGGTTAAAACGAA & & & \\
\hline & sea-2 & GAACСТTCCСATCAAAAACA & & & \\
\hline \multirow[t]{3}{*}{ seb } & & & 478 & 50 & (20) \\
\hline & seb-1 & TCGCATCAAACTGACAAACG & & & \\
\hline & seb-2 & GCGGTACTCTATAAGTGCC & & & \\
\hline \multirow[t]{3}{*}{ sec } & & & 257 & 50 & $(20)$ \\
\hline & $\sec -1$ & GACATAAAAGCTAGGAATTT & & & \\
\hline & sec-2 & AAATCGGATTAACATTATCC & & & \\
\hline \multirow[t]{3}{*}{ sed } & & & 317 & 50 & (20) \\
\hline & sed-1 & CTAGTTTGGTAATATCTCCT & & & \\
\hline & sed-2 & TAATGCTATATCTTATAGGG & & & \\
\hline \multirow[t]{3}{*}{ see } & & & 209 & 50 & (21) \\
\hline & see-1 & AGGTTTTTTCACAGGTCATCC & & & \\
\hline & see-2 & CTTTTTTTTCTTCGGTCAATC & & & \\
\hline \multirow[t]{3}{*}{ seg } & & & 287 & 55 & $(22)$ \\
\hline & seg-1 & AAGTAGACATTTTTGGCGTTCC & & & \\
\hline & $\operatorname{seg}-2$ & AGAACCATCAAACTCGTATAGC & & & \\
\hline \multirow[t]{3}{*}{ seh } & & & 213 & 46.4 & $(22)$ \\
\hline & she-1 & GTCTATATGGAGGTACAACACT & & & \\
\hline & she-2 & GACCTTTACTTATTTCGCTGTC & & & \\
\hline \multirow[t]{3}{*}{ sei } & & & 454 & 50 & (22) \\
\hline & sie-1 & GGTGATATTGGTGTAGGTAAC & & & \\
\hline & sie-2 & ATCCATATTCTTTGCCTTTACCAG & & & \\
\hline \multirow[t]{3}{*}{ sej } & & & 142 & 50 & (23) \\
\hline & sej-1 & CATCAGAACTGTTGTTCCGCTAG & & & \\
\hline & sej-2 & CTGAATTTTACCATCAAAGGTAC & & & \\
\hline
\end{tabular}

Table 2. Prevalence and Enterotoxins of S. aureus Isolated from Chicken Nugget Samples of Five Brands

\begin{tabular}{|c|c|c|c|c|c|c|c|c|c|c|}
\hline \multirow{2}{*}{ Brand } & \multirow{2}{*}{ No. of Samples } & \multicolumn{2}{|c|}{ No. of Samples With Positive Results } & \multicolumn{7}{|c|}{ Staphylococcal Enterotoxins (SEs), \% } \\
\hline & & S.aureus & Enterotoxigenic S. aureus & SEA & SEB & SEC & SED & SEE & SEA+SEC & SEA+SED \\
\hline $\mathbf{A}$ & 84 & 4 & 4 & 3 & - & 1 & - & - & - & - \\
\hline B & 84 & 4 & 3 & 1 & - & - & - & - & - & 2 \\
\hline C & 84 & 6 & 4 & 2 & 1 & - & - & - & 1 & - \\
\hline D & 84 & 3 & 3 & - & - & 2 & 1 & - & - & - \\
\hline $\mathbf{E}$ & 84 & 7 & 6 & 2 & - & - & 1 & - & 2 & 1 \\
\hline Total & 420 & 24 & 20 & 8 & 1 & 3 & 2 & - & 3 & 3 \\
\hline
\end{tabular}

Table 3. Enterotoxins Genes (sea through sej) in 23 S. aureus Bacteria Isolated From Five Brands Nugget Samples (A through E) in Iran

\begin{tabular}{lcccccc}
\hline \multirow{2}{*}{ Genotypic Profile } & \multirow{2}{*}{ Total } & \multicolumn{5}{c}{ Positive Results for S. aureus } \\
\cline { 3 - 7 } & & $\mathbf{A}(\mathbf{n}=\mathbf{4})$ & $\mathbf{B}(\mathbf{n}=\mathbf{4})$ & $\mathbf{C}(\mathbf{n}=\mathbf{6})$ & $\mathbf{D}(\mathbf{n}=\mathbf{3})$ & $\mathbf{E}(\mathbf{n}=7)$ \\
\hline $\boldsymbol{a}$ & 6 & 3 & 1 & - & - & 2 \\
$\boldsymbol{c}$ & 3 & 1 & - & - & - & - \\
$\boldsymbol{d}+\boldsymbol{j}$ & 1 & - & - & - & 1 & 1 \\
$\boldsymbol{d}+\mathbf{g}$ & 1 & - & - & - & - & - \\
$\mathbf{g}+\boldsymbol{i}$ & 1 & - & - & 1 & - & - \\
$\boldsymbol{a}+\mathbf{g}$ & 2 & - & - & - & - \\
$\boldsymbol{b}+\boldsymbol{j}+\boldsymbol{i}$ & 1 & - & - & - & - & 1 \\
$\boldsymbol{a}+\boldsymbol{d}$ & 3 & - & - & 1 & 2 \\
$\boldsymbol{a}+\boldsymbol{c}+\boldsymbol{j}$ & 3 & - & & & - & - \\
\hline
\end{tabular}


Figure 1. PCR Amplification of Enterotoxigenic Genes of S. aureus Isolated From Chicken Nugget in Iran

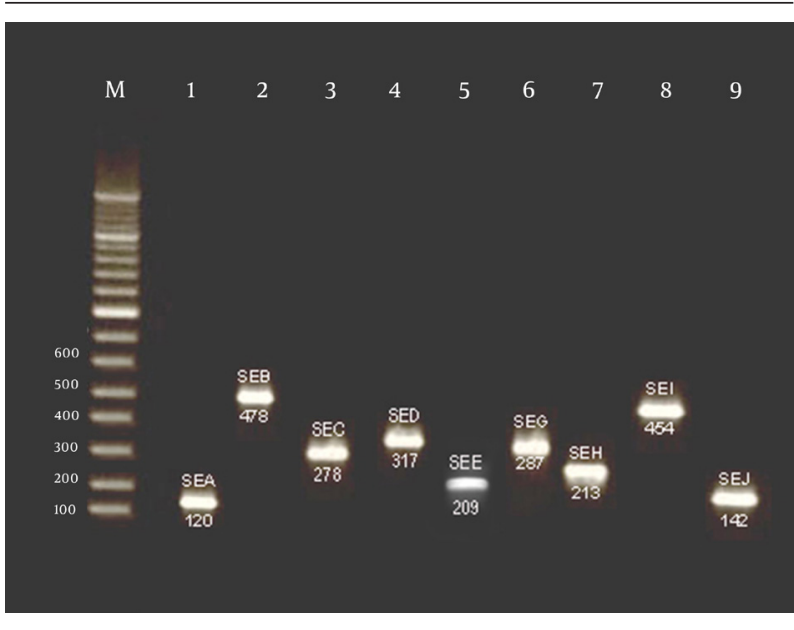

"M" is 100 bp ladder and " 2 " through " 9 " are positive samples. The figure of four different PCR amplifications has been merged in this

\section{Results}

In this study, contamination with S. aureus was detected in 27 (6.42\%) out of 420 samples with the concentration between $6.1 \times 10^{3}$ to $8.4 \times 10^{1} / \mathrm{mL}$. No significant differences were observed in the prevalence rates of $S$. aureus between chicken nugget samples collected from different brands in Chaharmahal-va-Bakhtiari and Isfahan provinces. Table 2 the prevalence of S. aureus and SEs isolated from chicken nugget samples in Chaharmahal-vaBakhtiari and Isfahan, Iran. The ability to synthesize classical SEs was found in 20 (83.3\%) out of 24 isolates. Eight isolates (33.33\%) produced SEA, 1 (4.16\%) SEB, 3 (12.50\%) SEC 2 (8.33\%) SED, 3 (12.50\%) SEA + SEC, and 3 (12.50\%) SEA + SED (Table 1). No SEE was identified in nugget samples. Table 3 the results of PCR for the detection of genes encoding the SEA-SEJ enterotoxins (Figure 1). Of the 24 strains of S. aureus tested, 23 (95.83\%) had positive results for one or more SEs genes and five different genotypes were observed. Nine strains possessed only one type of SEs genes and the reimagining isolates harbored more than one SEs genes. The most commonly detected genes were sea (25\%), sea $+\operatorname{seg}(8.33 \%), \sec (12.50 \%)$, sea $+\operatorname{sed}(12.50 \%)$, and sea $+\sec +\operatorname{sej}(12.50 \%)$. No see gene was detected in any of the isolates.

\section{Discussion}

Our results showed the low presence of S. aureus in chicken nugget samples (6.42\%) that is in contrast with previous studies $(7,24)$. Only three studies were performed concerning detection of $S$. aureus in poultry samples in Iran (12-14), which are in agreement with our results. Javadi and Safarmashaei showed the presence of S. aureusin $65 \%$ of poultry samples (12), which was significantly more prevalent than in our samples (6.412\%). Feizi et al. (14) reported that $81.75 \%$ of Iranian poultry farms were contaminated with S. aureus. A study in Taiwan showed S. aureus presence in $7.8 \%$ of chicken carcasses (25), which is almost the same as our investigation results.

According to the study of Gencay et al., 65.6\% (21/32)of the beef, 55\% (11/20) of the poultry (5/9 for chicken meat and $6 / 11$ for turkey meat), $73.9 \%$ (17/23) of the dairy products, $77.7 \%$ (14/18) of the ready to eat foods, and $77.7 \%$ (7/9) of the food ingredients were contaminated with S. aureus (26). We found SEA-SED produced by S. aureus in chicken nugget and it was in agreement with the previous studies $(22,23,27)$. Previous investigations indicated that SEs genes are mostly involved in outbreaks of staphylococcal food poisoning $(23,27,28)$. A Turkish investigation showed that only $2.9 \%$ of 70 tested S. aureus strains were positive for sea gene while there were no positive results for other putative genes (26).

Our results showed that sea, seg, sec, sed, and sejgenes had a high prevalence in chicken nugget. Previous study showed that the frequency of the strains harboring seg, seh, sei, and sej genes was very high (57\%) and greater than sea, seb,sec, sed, and see genes (28). Akineden et al. (27) showed that $67.96 \%$ of $S$. aureus isolates had one or more SEs genes including sea, sec, sed, seg, sei, and sej, which was significantly more prevalent than in our strains. The highest amounts of SEs genes have been reported by Omoe et al. (22) who reported SEs genes in 100\% of S. aureus isolates). Lim et al. (23) determined $22.28 \%$ of $S$. aureus isolates harbored sea, seb, and sec genes while sea was the most frequent SEs gene (86.48\%), which was in agreement with our study. The prevalence rates of sea, sec and sea plus sec among the total clinical isolates in Jordan were $15 \%, 4 \%$, and $4 \%$, respectively.

According to our results and the results of previous investigations, the sea gene of S. aureus has the highest prevalence of virulence genes. Similar results have been reported by other Iranian authors $(29,30)$. Soltan Dallal et al. indicated that from a total of $100 \mathrm{~S}$. aureus strains isolated from 1047 food samples, toxic shock syndrome toxin-1 (TSST1) was detected in 12 strains and $66.7 \%$ of them belonged to the human biotype. In addition, they reported that the most prevalent spa (S. aureus protein A) types of S. aureus isolated from 913 food samples were D (20\%) and C (16\%) in dairy products and D (6\%) and E (3\%) in meat products (30). It seems that the epidemiology and prevalence of $S$. aureus isolated from poultry nugget samples in Iran is different. Probably accurate inspection of poultry, hygienic condition in slaughterhouses, and processing and maintenance of meats in suitable condition and away from heat are the main reasons involved in the prevalence of $S$. aureus in poultry nugget samples of $S$. aureus in foods indicates the contamination of foods by workers who have skin lesions containing S. aureus, sneezing, or coughing (31). Therefore, using raw chicken meat, application of unhygienic techniques for meat 
Madahi H et al.

processing, not keeping chicken carcasses in cool and dry places and away from sunlight, and finally, meat contaminated with extrinsic factors like insects and dust are the main causes of growth, proliferation, and survival of S. aureus. In these cases, the suitable temperature, humidity, and food resources cause increased production of virulence factors. Therefore, food poisoning easily occurs. As far as we know, this study is the first prevalence report of enterotoxigenic $S$. aureus and its SEs genes isolated from chicken nugget. The results of this study showed that:

1) The $S$. aureus can easily contaminate the chicken nugget and usually this contamination is associated with high presences of virulence genes.

2) It seems that processing with unhygienic methods and lack hygiene of the poultry slaughterhouse staff as well as factories are the main factors for contamination of chicken nuggets.

3) The multiplex PCR assay can be used as an accurate, safe, and fast technique for the detection of S. aureus and its virulence factors in chicken nugget samples.

It can be concluded that due to the occurrence of $S$. aureus in nugget samples, some food safety and quality standards (good agricultural practices [GAPs], good manufacturing practices [GMPs], and the hazard analysis and critical control point [HACCP] system) need to be applied and performed in most of Iranian food units to control growth of $S$. aureus and virulence genes production during harvesting, distribution, and storage periods. The moisture content of nuggets should be monitored, and storage and transport should be modified according to what has been observed in the models. Therefore, further studies should be performed on different Iranian foods to detect the presence of S. aureus and its virulence factors.

\section{Acknowledgements}

The authors would like to thank Dr. F. Safarpoor Dehkordi for his important technical and clinical support.

\section{Authors' Contribution}

Hajar Madahi, Fatemeh Rostami, and Mohammad Jalali performed statistical analysis and revised the manuscript; Farhad Safarpoor Dehkordi, Ebrahim Rahimi, and Hassan Momtaz performed PCR amplification, electrophoresis, and DNA extraction; Farhad Safarpoor Dehkordi wrote the manuscript.

\section{Funding/Support}

This work was supported by Islamic Azad University, Shahrekord, IR Iran, with grant number: 90/9025.

\section{References}

1. Sidhu MS, Oppegaard H, Devor TP, Sorum H. Persistence of multidrug-resistant Staphylococcus haemolyticus in an animal veterinary teaching hospital clinic. Microb Drug Resist. 2007;13(4):271-
80.

2. Capita R, Alonso-Calleja C, Garcia-Fernandez MC, Moreno B. Characterization of Staphylococcus aureus isolated from poultry meat in Spain. Poultry Sci. 2002;81(3):414-21.

3. Hermans JJ, Ginai AZ, Wentink N, Hop WC, Beumer A. The additional value of an oblique image plane for MRI of the anterior and posterior distal tibiofibular syndesmosis. Skeletal Radiol. 2011;40(1):75-83.

4. Foster TJ. Potential for vaccination against infections caused by Staphylococcus aureus. Vaccine.1991;9(4):221-7.

5. Witte W. Antibiotic resistance in gram-positive bacteria: epidemiological aspects. J Antimicrob Chemother. 1999;44 Suppl A:1-9.

6. Hwang SY, Kim SH, Jang EJ, Kwon NH, Park YK, Koo HC, et al. Novel multiplex PCR for the detection of the Staphylococcus aureus superantigen and its application to raw meat isolates in Korea. Int $J$ Food Microbiol. 2007;117(1):99-105.

7. Kwon NH, Park KT, Jung WK, Youn HY, Lee Y, Kim SH, et al. Characteristics of methicillin resistant Staphylococcus aureus isolated from chicken meat and hospitalized dogs in Korea and their epidemiological relatedness. Vet Microbiol. 2006;117(2-4):304-12.

8. Mallikarjunan P, Ngadi MO, Chinnan MS. Breaded Fried Foods: Taylor \& Francis; 2004

9. Balaban N, Rasooly A. Analytical chromatography for recovery of small amounts of staphylococcal enterotoxins from food. Int J Food Microbiol. 2001;64(1-2):33-40.

10. Akineden O, Hassan AA, Schneider E, Usleber E. Enterotoxigenic properties of Staphylococcus aureus isolated from goats' milk cheese. Int J Food Microbiol. 2008;124(2):211-6.

11. Hermans K, Devriese LA, Haesebrouck F. Staphylococcus. 2010:75-89.

12. Javadi A, Safarmashaei S. Microbial profile of marketed broiler meat. Middle East J Sci Res; 2011.

13. Nemati M, Hermans K, Lipinska U, Denis O, Deplano A, Struelens $\mathrm{M}$, et al. Antimicrobial resistance of old and recent Staphylococcus aureus isolates from poultry: first detection of livestockassociated methicillin-resistant strain ST398. Antimicrob Agents Chemother. 2008;52(10):3817-9.

14. Feizi A, Nazeri M. Isolation of Staphylococcus spp. genera from broiler breeder flocks in East Azerbaijan Province of Iran: Prevalence and antimicrobial susceptibility. Afr J Microbiol Res. 2012;6(29).

15. Kiedrowski MR, Kavanaugh JS, Malone CL, Mootz JM, Voyich JM, Smeltzer MS, et al. Nuclease modulates biofilm formation in community-associated methicillin-resistant Staphylococcus aureus. PLoS One. 2011;6(11).

16. Rahimi E, Safai HG. Detection of classical enterotoxins of Staphylococcus aureus strains isolated from bovine subclinical mastitis in Isfahan, Iran. Vet Microbiol. 2010;141(3-4):393-4.

17. Sambrook J, Russell DW. Standard methods for DNA manipulations. Molecular Cloning A Laboratory Manual. New York: Cold Spring Harbor Laboratory; 2001

18. Zouharova M, Rysanek D. Multiplex PCR and RPLA Identification of Staphylococcus aureus enterotoxigenic strains from bulk tank milk. Zoonoses Public Health. 2008;55(6):313-9.

19. Rall VL, Vieira FP, Rall R, Vieitis RL, Fernandes A, Jr, Candeias JM, et al. PCR detection of staphylococcal enterotoxin genes in Staphylococcus aureus strains isolated from raw and pasteurized milk. Vet Microbiol. 2008;132(3-4):408-13.

20. Johnson WM, Tyler SD, Ewan EP, Ashton FE, Pollard DR, Rozee KR. Detection of genes for enterotoxins, exfoliative toxins, and toxic shock syndrome toxin 1 in Staphylococcus aureus by the polymerase chain reaction. J Clin Microbiol. 1991;29(3):426-30.

21. Mehrotra M, Wang G, Johnson WM. Multiplex PCR for detection of genes for Staphylococcus aureus enterotoxins, exfoliative toxins, toxic shock syndrome toxin 1 , and methicillin resistance. $J$ Clin Microbiol. 2000;38(3):1032-5.

22. Omoe K, Ishikawa M, Shimoda Y, Hu DL, Ueda S, Shinagawa K. Detection of seg, seh, and sei genes in Staphylococcus aureus isolates and determination of the enterotoxin productivities of S. aureus isolates Harboring seg, seh, or sei genes.J Clin Microbiol. 2002;40(3):857-62.

23. Lim SK, Joo YS, Moon JS, Lee AR, Nam HM, Wee SH, et al. Molecular 
typing of enterotoxigenic Staphylococcus aureus isolated from bovine mastitis in Korea. J Vet Med Sci. 2004;66(5):581-4.

24. McMahon WA, Aleo VA, Schultz AM, Horter BL, Lindberg KG. 3M Petrifilm Staph Express Count plate method for the enumeration of Staphylococcus aureus in selected types of meat, seafood, and poultry: collaborative study. JAOAC Int. 2003;86(5):947-53.

25. Lin J, Yeh KS, Liu HT, Lin JH. Staphylococcus aureus isolated from pork and chicken carcasses in Taiwan: prevalence and antimicrobial susceptibility. J Food Protect. 2009;72(3):608-11.

26. Gencay YE, Ayaz ND, Kasımoglu-Dogru A. Enterotoxin gene profiles of Staphylococcus aureus and other Staphylococcal isolates from various foods and food ingredients. Erciyes Üniversitesi Veteriner Fakültesi Dergisi. 2010;7(2):75-80.

27. Akineden O, Annemuller C, Hassan AA, Lammler C, Wolter W, Zschock M. Toxin genes and other characteristics of Staphylococ- cus aureus isolates from milk of cows with mastitis. Clin Diagn Lab Immunol. 2001;8(5):959-64.

28. Rosec JP, Gigaud O. Staphylococcal enterotoxin genes of classical and new types detected by PCR in France. Int J Food Microbiol. 2002;77(1-2):61-70.

29. Soltan-Dallal MM, Salehipour Z, Mehrabadi JF. Molecular epidemiology of Staphylococcus aureus in food samples based on the protein A gene polymorphic region DNA sequence. Can J Microbiol. 2010;56(1):18-21.

30. Soltan Dallal MM, Salehipour Z, Eshraghi S, Fallah Mehrabadi J, Bakhtiari R. Occurrence and molecular characterization of Staphylococcus aureus strains isolated from meat and dairy products by PCR-RFLP. Ann Microbiol. 2010;60(2):189-96.

31. Jay JM, Loessner MJ, Golden DA. Modern Food Microbiology. New York: Springer; 2005 